\title{
Improvement in $\beta$-glucan extraction from Ganoderma lucidum with high-pressure steaming and enzymatic pre-treatment
}

\author{
In-Wook Hwang ${ }^{1} \cdot$ Bo-Min Kim² ${ }^{2}$ Young-Chan Kim ${ }^{3}$ • \\ Sang-Han Lee ${ }^{2} \cdot$ Shin-Kyo Chung ${ }^{2,4}$
}

Received: 30 October 2017/ Accepted: 7 February 2018/Published online: 23 February 2018

(C) The Korean Society for Applied Biological Chemistry 2018

\begin{abstract}
In this study, the high-pressure steaming and enzymatic pre-treatment (SET) was used to improve $\beta$ glucan extraction from Ganoderma lucidum (G. lucidum), an oriental medicinal mushroom. Response surface methodology and central composite design were used to determine the optimum pre-treatment conditions: highpressure steaming, enzymatic hydrolysis, and Viscozyme L concentrations. The optimal conditions were $15.51 \mathrm{~min}$ for high-pressure steaming, $0.84 \mathrm{~g} / 100 \mathrm{~mL}$ of Viscozyme L, and $4.16 \mathrm{~h}$ for hydrolysis. The predicted $\beta$-glucan content in G. lucidum extract at optimal conditions, approximately twofold $(8.05 \mathrm{~g} / 100 \mathrm{~g})$ of the control treatment value, was consistent with the empirical value. The total sugar and protein contents through SET were higher than those values of the control treatment. The cell migration assay showed that SET-processed G. lucidum extracts significantly suppressed B16F10 murine melanoma cell growth. SET process using Viscozyme $L$ could be utilized for $\beta$ glucan extraction from $G$. lucidum to develop the functional food.
\end{abstract}

Keywords Anti-metastatic effect - Ganoderma lucidum . $\beta$-Glucan · Steaming · Viscozyme L

Shin-Kyo Chung

kchung@knu.ac.kr

1 Department of Food Science and Nutrition, Dong-A University, Busan 49315, Republic of Korea

2 School of Food Science and Biotechnology, Kyungpook National University, Daegu 41566, Republic of Korea

3 Korea Food Research Institute, Wanju-gun, Jeollabuk-do 55365, Republic of Korea

4 Food and Bio-Industry Research Institute, Kyungpook National University, Daegu 41566, Republic of Korea

\section{Introduction}

Ganoderma lucidum, which is an oriental mushroom belonging to Basidiomycetes, has several medicinal properties and has been used in traditional medicine in many Asian countries, including Korea [1]. The mushroom is rich in carbohydrates, proteins, lipids, minerals, and vitamins [2], and its medicinal effects are attributed to its polysaccharide, triterpene, polyphenol, nucleoside, and steroid contents [3]. The polysaccharides of G. lucidum have antioxidant [4], anti-aging [5], and anti-tumor effects [6, 7]; they also boost the immune system [8] and reduce blood sugar and lipid levels $[9,10]$. $\beta$-Glucan, in particular, inhibits cancer cell growth by activating the immune response in normal cells [11]. Studies have shown that $\beta$ glucan promotes the production of interferon gamma and interleukin-12 (IL-12) in lymphocytes [12] and induces the $\mathrm{T}$ helper 1 reaction by increasing the production of interleukin-1 (IL-1), tumor necrosis factor alpha (TNF- $\alpha$ ), and nitric oxide [13].

$\beta$-Glucan consists of $\beta$-D-glucose polysaccharides, which occurs naturally in the cell walls of mushrooms and fungi group [14]. The most common form of $\beta$-glucan is Dglucose with $\beta-1 \rightarrow 3$ linkages, occasionally with $\beta-1 \rightarrow 6$ branching side chains in certain structures [15]. The extent of branching in $\beta$-glucan affects its molecular weight, solubility, and physiological functions [16]. Generally, hot water extraction is used for extracting $\beta$-glucan for subsequent use as a healthcare product [17]. Various strains of G. lucidum contain 12.4-19.0 g/100 g of $\beta$-glucan [11]. However, the yield of $\beta$-glucan obtained by hot water extraction is considerably low because of the solid woody tissue of G. lucidum. The yield of extracted $\beta$ glucan increases with temperature [18], supercritical fluids 
[19], and pressurized hot water [20, 21] from mushrooms. However, there is a paucity of research on the $\beta$-glucan extraction from $G$. lucidum by the combined pre-treatment with the high-pressure steaming and hydrolyzing enzymes which facilitate the extraction of polysaccharides by weakening the hydrogen bonding within plant tissues and cell walls $[22,23]$.

In this study, we improved the yield of $\beta$-glucan extracted from G. lucidum using SET. Response surface methodology (RSM) and central composite design (CCD) were used to determine the optimal conditions of extraction, and the physicochemical properties and anticancer activities of the extracts were determined.

\section{Materials and methods}

\section{Materials and chemicals}

Ganoderma lucidum mushrooms were obtained from the area of cultivation (Chilgok, Korea) and were stored at $4{ }^{\circ} \mathrm{C}$. The sample for $\beta$-glucan extraction was pulverized and screened through a 25-mesh sieve to obtain a powder. Viscozyme L (Aspergillus aculeatus, 100 FBG/g, Novozymes A/S, Bagsvaered, Denmark) and bovine serum albumin were purchased from Sigma Chemical Co. (St. Louis, MO, USA). Citric acid, sodium hydroxide, sodium acetate, potassium hydroxide, and hydrochloric acid were purchased from Duksan Pure Chemical Co. Ltd (Seoul, Korea). SET was performed using an autoclave (ILSHIN autoclave Co. Ltd, Daejeon, Korea) and a shaking incubator (SW-90R, Sang Woo Scientific Corp., Seoul, Korea).

\section{Experimental design for response surface methodology}

RSM was used to determine the optimum conditions for the pre-treatment of G. lucidum. Experiment and statistical analyses were performed using SAS version 9.1 (SAS Institute, Inc., Cary, NC, USA). CCD with a quadratic model was employed [24]. Three independent variables, namely high-pressure steaming time $\left(X_{1}\right)$, enzyme concentration $\left(X_{2}\right)$, and enzymatic hydrolysis time $\left(X_{3}\right)$, were selected. Each independent variable had five levels, namely $-2,-1,0,+1$, and +2 . Sixteen different combinations (including duplicates of the center point, each assigned with the coded value 0 ) were selected in random according to a CCD configuration for three factors [25]. The variance for each factor was partitioned into linear, quadratic, and interactive components and was represented as:
$Y=\beta_{0}+\sum_{i=1}^{j} \beta_{i} X_{j}+\sum_{i=1}^{j} \beta_{i i} X_{i}^{2}+\sum \sum_{i \neq j=1}^{j} \beta_{i j} X_{i} X_{j}$,

where $\beta_{0}$ is a constant, $\beta_{i}$ is a linear coefficient, $\beta_{i i}$ is a quadratic coefficient, $\beta_{i j}$ is a cross-product coefficient, and $X_{i}$ and $X_{j}$ are the levels of the independent variables. Threedimensional plots were constructed by keeping one variable constant at the center point and varying the other two variables within the experimental range. Analysis of variance (ANOVA), which is a partial $F$-test for individual terms, and an analysis of residuals were performed. ANOVA tables were generated, and the effects and regression coefficients of individual linear, quadratic, and interaction terms were determined. The degrees of significance of all the terms in the polynomial were determined statistically by calculating the $F$ value at a probability $(p)$ of $0.001,0.01,0.05$, or 0.1 .

\section{$\beta$-Glucan extraction}

A mixture of $1 \mathrm{~g}$ of $\mathrm{G}$. lucidum powder in $20 \mathrm{~mL}$ of distilled water was subjected to different conditions of highpressure steaming $\left(121{ }^{\circ} \mathrm{C}\right.$ and $15 \mathrm{lb}$ psi) and enzymatic hydrolysis using the autoclave and shaking incubator $\left(50{ }^{\circ} \mathrm{C}\right.$ and $\left.120 \mathrm{rpm}\right)$, respectively. The enzymatic hydrolysis was carried out by cooling to $50{ }^{\circ} \mathrm{C}$ after the high-pressure steaming. The ranges of the variables were based on the preliminary experiment. The independent variables for the conditions of $\beta$-glucan extraction were high-pressure steaming time $X_{1}(0-20 \mathrm{~min})$, enzyme concentration $X_{2}(0-1 \mathrm{~g} / 100 \mathrm{~mL})$, and enzymatic hydrolysis time $X_{3}(1-5 \mathrm{~h})$. The temperatures of the enzymatic treatment were adjusted using a water bath at constant temperature. The hydrolyzed samples were adjusted to $\mathrm{pH} 10$ with $1 \mathrm{~N}$ sodium hydroxide, followed by reflux extraction at $90{ }^{\circ} \mathrm{C}$ for $6 \mathrm{~h}$. Control treatment was carried out only under reflux extraction. The final extracts were used for physicochemical analyses and analysis of inhibitory effects on cancer cells after lyophilization.

\section{Chemical analyses}

The $\beta$-glucan contents in the extracts were determined using the $\beta$-glucan assay kit (yeast $\&$ mushroom, Megazyme, Ireland) [26]. The extraction yields were determined by a drying method using an oven at $105^{\circ} \mathrm{C}$. Purity was expressed as $\beta$-glucan content per total glucan content in percentage. The protein contents were determined by the bicinchoninic acid assay [27]. The total sugar contents were determined by the phenol-sulfuric acid method [28]. After hydrolysis with hydrochloric acid, the monosaccharide composition of the extracts was analyzed using a high- 
performance liquid chromatograph (HPLC, 1260 Infinity Quaternary LC System, Agilent Technologies, Waldbronn, Germany) equipped with a refractive index detector and a carbohydrate analysis column $(3.9 \times 300 \mathrm{~mm}$, Waters, Milford, MA, USA) with $80 \%$ acetonitrile at a flow rate of $1.5 \mathrm{~mL} / \mathrm{min}$ [29]. Glucose, mannose, galactose, and fructose were used as standard.

\section{Cell culture}

The B16F10 murine melanoma cell line was obtained from the American Type Culture Collection (American Type Culture Collection, Manassas, VA, USA) and cultured in Dulbecco's modified Eagle's medium (DMEM; Life technologies, Grand Island, NY, USA) containing $10 \%$ fetal bovine serum (Life technologies) and a mixture (Sigma-Aldrich, St. Louis, MO, USA) of 100 units $/ \mathrm{ml}$ penicillin and $100 \mu \mathrm{g} / \mathrm{ml}$ streptomycin sulfate in a humidified, $5 \% \mathrm{CO}_{2}$ atmosphere.

\section{Proliferation assay}

MTT assay was carried out to evaluate the viability of the cells cultured with the G. lucidum extracts [30]. In brief, the cells were plated in 96-well plates and incubated for $24 \mathrm{~h}$ in $100 \mu \mathrm{L}$ of DMEM. The G. lucidum extract at various concentrations $(1,3,10,30$, and $100 \mu \mathrm{g} / \mathrm{mL})$ was added to the cells, and the cells were incubated for an additional $24 \mathrm{~h}$. Then, $10 \mu \mathrm{L}$ of the MTT solution ( $5 \mathrm{mg} /$ $\mathrm{mL}$ MTT in phosphate-buffered saline) was added to each well, followed by incubation at $37^{\circ} \mathrm{C}$ for $1 \mathrm{~h}$. After removing the MTT solution, $100 \mu \mathrm{L}$ of dimethyl sulfoxide was added to each well with vigorous mixing. The absorbance at $470 \mathrm{~nm}$ was measured using a Victor multilabel counter (Wallac; Turku, Finland).

\section{Cell migration assay}

The B16F10 cells, which were cultured in a 6-well plate $\left(3.0 \times 10^{5}\right.$ cells $\left./ \mathrm{mL}\right)$, were incubated for $24 \mathrm{~h}$ at $37^{\circ} \mathrm{C}$ in a $5 \% \mathrm{CO}_{2}$ atmosphere. Then, the cells were scratched with a $200-\mu \mathrm{L}$ pipette tip and further incubated with different concentrations of the $G$. lucidum extracts (1, 10, and $100 \mu \mathrm{g} / \mathrm{mL})$ and resveratrol $(10 \mu \mathrm{g} / \mathrm{mL}$, positive control), which served as a positive control, for $12 \mathrm{~h}$ at $37^{\circ} \mathrm{C}$. Cell migration on the slit of the confluent well was assessed at 0,6 , and $12 \mathrm{~h}$ in each condition. The plates were photographed at 16, 24, and $40 \mathrm{~h}$, and the exact width of the wound was calculated using a micro-ruler [31].

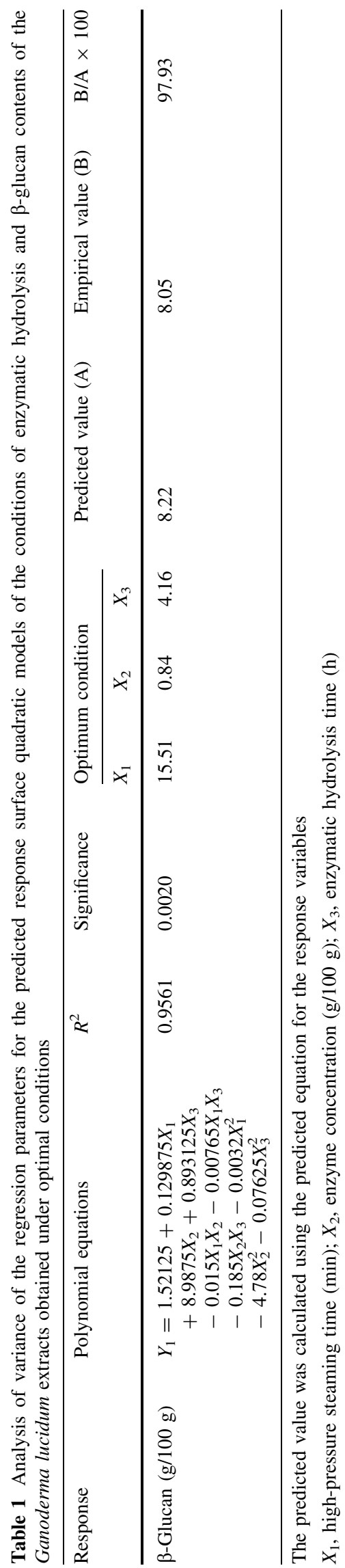




\section{Statistical analysis}

The data are expressed as mean \pm standard deviation (SD) of triplicate experiments. One-way ANOVA and Duncan's new multiple range test were performed to determine significant differences between the means with SAS version 9.1 (SAS Institute, Inc., Cary, NC, USA). $p$ values $<0.05$ were considered statistically significant.

\section{Results and discussion}

\section{Modeling of the pre-treatment conditions for $\beta$ - glucan extraction}

Generally, the yield of $\beta$-glucan from G. lucidum is low because of the rigidity of the woody tissue. Therefore, we employed high-pressure steaming and enzymatic hydrolysis treatment to overcome this drawback. We used RSM to evaluate the interaction between the various treatment parameters and their relationship with the dependent variable [32]. Using RSM, we also generated a mathematical model with minimal experimentation and investigation for determining the optimal conditions [33]. Therefore, we used RSM to determine the optimum pre-treatment conditions in the range of the suggested variables. A duration of $10 \mathrm{~min}$ of high-pressure steaming, a Viscozyme L-tosubstrate ratio of $0.5 \mathrm{~g} / 100 \mathrm{~mL}$, and a duration of $3 \mathrm{~h}$ of enzymatic hydrolysis were selected from the preliminary experiments as the main conditions of the central composite rotatable design. The $\beta$-glucan contents differed significantly with the treatment conditions, ranging from $4.08 \mathrm{~g} / 100 \mathrm{~g}$ to $8.14 \mathrm{~g} / 100 \mathrm{~g}$. $R^{2}$, which is the coefficient of determination, is defined as the ratio of the explained variation to the total variation, and is a measure of the degree of fitness [34]. The empirical model fits the actual data better as $R^{2}$ approaches unity. As shown in Table 1, the $R^{2}$ value for the response variable ( $\beta$-glucan contents) was 0.9561 , which indicated the fitness of the regression model for the pre-treatment reactions.
Improvement in $\beta$-glucan extraction from $\boldsymbol{G}$. lucidum by SET

Viscozyme $\mathrm{L}$ is composed of a multi-enzyme complex with a wide range of hydrolyzing enzymes $[35,36]$. Therefore, it is assumed that Viscozyme L might decompose cellulose and pectin substances in the G. lucidum cell wall and could increase the extraction yield of $\beta$-glucan. The scores of significance of the effects of high-pressure steaming time, enzyme concentration, and enzymatic hydrolysis time on $\beta$-glucan contents are shown in Table 2 . Figure 1 illustrates the four-dimensional response surfaces for $\beta$-glucan contents at constant values of 5,7 , and $8 \mathrm{~g} / 100 \mathrm{~g}$ constructed using the regression equation of the response

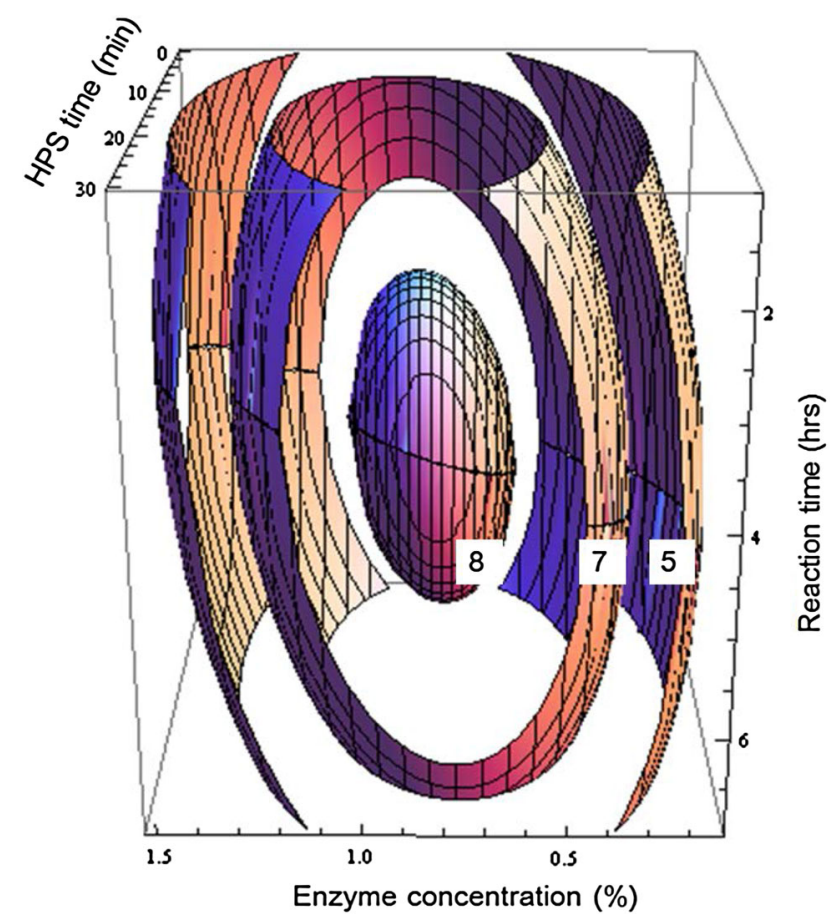

Fig. 1 Four-dimensional response surfaces for $\beta$-glucan contents (at constant values, 5, 7, $8 \mathrm{~g} / 100 \mathrm{~g}$ ) of the Ganoderma lucidum extracts as functions of high-pressure steaming time, ratio of enzyme concentration-to-substrate concentration, and enzymatic hydrolysis time in $\beta$-glucan extraction
Table 2 Analysis of variance of the overall effects of the pretreatment conditions for the extraction of $\beta$-glucan from Ganoderma lucidum

\begin{tabular}{lccc}
\hline & $F$ value & $p$ value & Critical value \\
\hline High-pressure steaming time $\left(X_{1}\right)$ & 2.12 & 0.1962 & 15.51 \\
Enzyme concentration $\left(X_{2}\right)$ & $27.93^{* * * * *}$ & 0.0005 & 0.84 \\
Enzymatic hydrolysis time $\left(X_{3}\right)$ & 2.72 & 0.1319 & 4.16 \\
\hline
\end{tabular}

****Significant at $p<0.001$ 
surface analysis. It graphically demonstrates the effect of variables individually and in combination, and shows the nature of the stationary point of the fitted surface. As shown in Table 2 and Fig. 1, the $\beta$-glucan contents were significantly affected by enzyme concentration $(p<0.001)$, whereas high-pressure steaming time and enzymatic hydrolysis time had no significant effect. The $\beta$ glucan contents increased with enzyme concentration to the maximum value (high-pressure steaming for $15.51 \mathrm{~min}$, enzyme concentration of $0.84 \mathrm{~g} / 100 \mathrm{~mL}$, and hydrolysis with Viscozyme L for $4.16 \mathrm{~h}$ ) predicted by the stationary point $(8.22 \mathrm{~g} / 100 \mathrm{~g})$. The graphical approach allowed for the study of the influence of each parameter and determination of the optimal operating conditions required to obtain $\beta$-glucan. The results suggested that the optimum pre-treatment conditions might enhance the yield of extracted $\beta$-glucan. Similar studies reported that optimum pre-treatment conditions may enhance the efficiency of antioxidant extraction, whereas excessive treatment had a negative effect $[23,37]$. Based on practical considerations, the optimal high-pressure steaming time, enzyme concentration, and enzymatic hydrolysis time were determined to be $15.51 \mathrm{~min}, 0.84 \mathrm{~g} / 100 \mathrm{~mL}$, and $4.16 \mathrm{~h}$, respectively, based on which the $\beta$-glucan contents of the G. lucidum extracts were predicted to be $8.22 \mathrm{~g} / 100 \mathrm{~g}$ (Table 1). This value was in agreement with the empirical value $(8.05 \mathrm{~g} / 100 \mathrm{~g})$ of the optimum pre-treatment condition, which reflected the fitness of the optimization. The extraction of $\beta$-glucan from G. lucidum by SET $(p<0.05)$ increased twofold (19.89 g/100 g) (Table 3). These results were consistent with those of previous studies on steaming and enzymatic pre-treatments [37]. The extraction yield and contents of $\beta$-glucan, total sugar, monosaccharide, and protein in the SET processes of G. lucidum extract were compared with those of the control treatment (Table 3). The total sugar and protein contents of SET also increased twofold compared with those values of the control treatment. These results were closely associated with the enhanced yield of extraction through the pre-treatment conditions. The increase in soluble solid contents of persimmon peel through enzymatic treatment [37] and total sugar and protein contents of G. lucidum through pressurized extraction [39] was also reported. In contrast to glucose, mannose, and galactose which were detected in both control and the SET-processed extracts, fructose was only detected in the SET-processed extracts (Table 3). The free sugar contents of the SET-processed extract were higher than those of the control extract $(p<0.05)$. Glucose was the main sugar component of the G. lucidum extract, followed by mannose, galactose, and fructose $(p<0.05)$. Although the sugar composition varied depending on the growth environment, the hot water extract of G. lucidum contained glucose, galactose, mannose, and xylose [40].

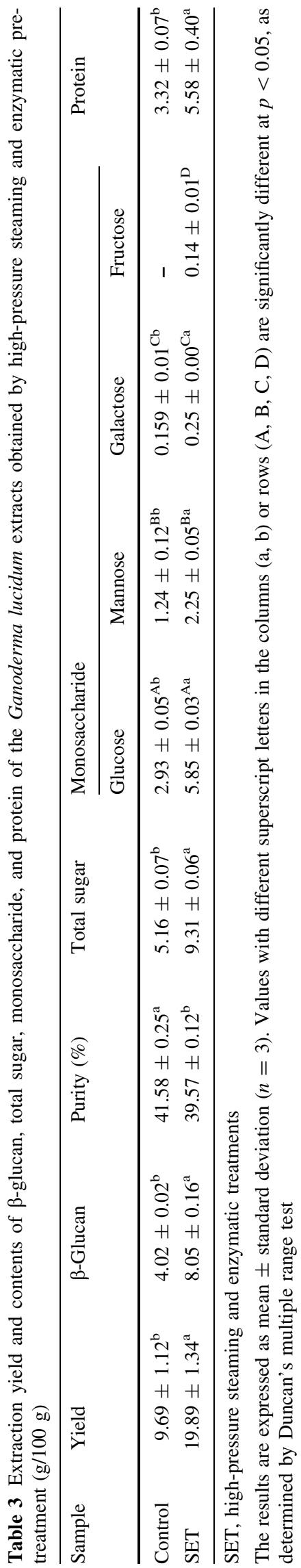


Increase in sugar and protein contents also indicated improvement in $\beta$-glucan yield by SET. Thus, we propose that high-pressure steaming in combination with Viscozyme $\mathrm{L}$ pre-treatment could be adopted for the extraction of $\beta$-glucan from G. lucidum.

\section{Anti-metastatic effect of the G. lucidum extracts}

To evaluate the anticancer activities of the G. lucidum extracts, we performed an MTT assay and a cell migration assay on the murine melanoma cell line B16F10. As shown in Fig. 2(A), all the samples exhibited a significant degree of cell viability of over $80 \%$ at all the extract concentrations. Therefore, it was confirmed that the G. lucidum
Fig. 2 Effect of the Ganoderma lucidum extracts obtained by high-pressure steaming and enzymatic pretreatment on the viability (A) and the migration (B) of B16F10 cells. CON, control; RES, resveratrol $(10 \mu \mathrm{g} / \mathrm{mL})$; NPT, non-pre-treatment; SET, steaming and enzymatic pretreatment; *,**, ***,

$* * * *$ significant difference from the control at $t<0.1, t<0.05$, $t<0.01, t<0.001$, respectively
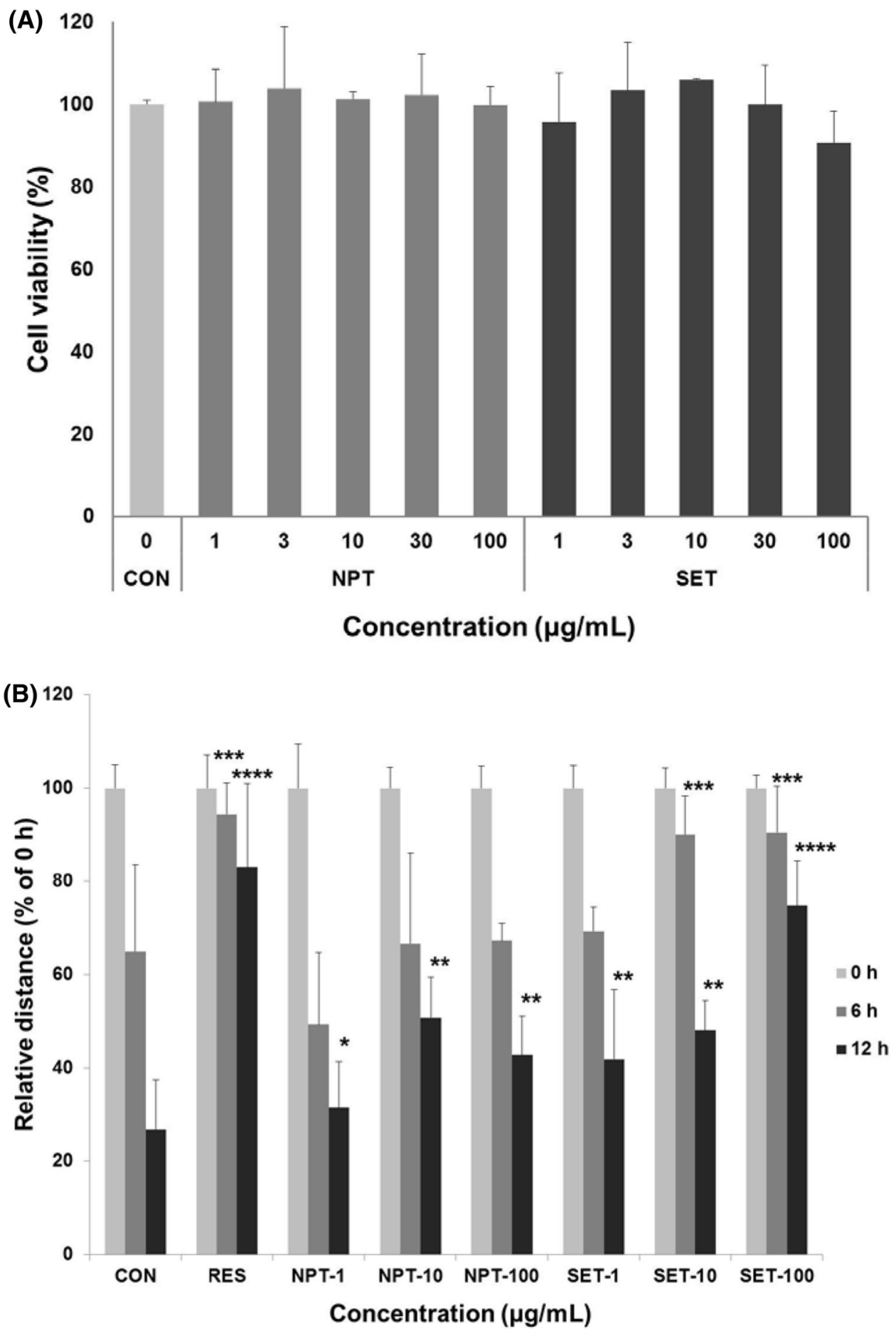
Fig. 3 Cell migration assay of the Ganoderma lucidum extracts obtained by highenzymatic pre-treatment with B16F10 cells. Resveratrol $(10 \mu \mathrm{g} / \mathrm{mL})$; NPT, non-pretreatment; SET, steaming and enzymatic pre-treatment pressure steaming and

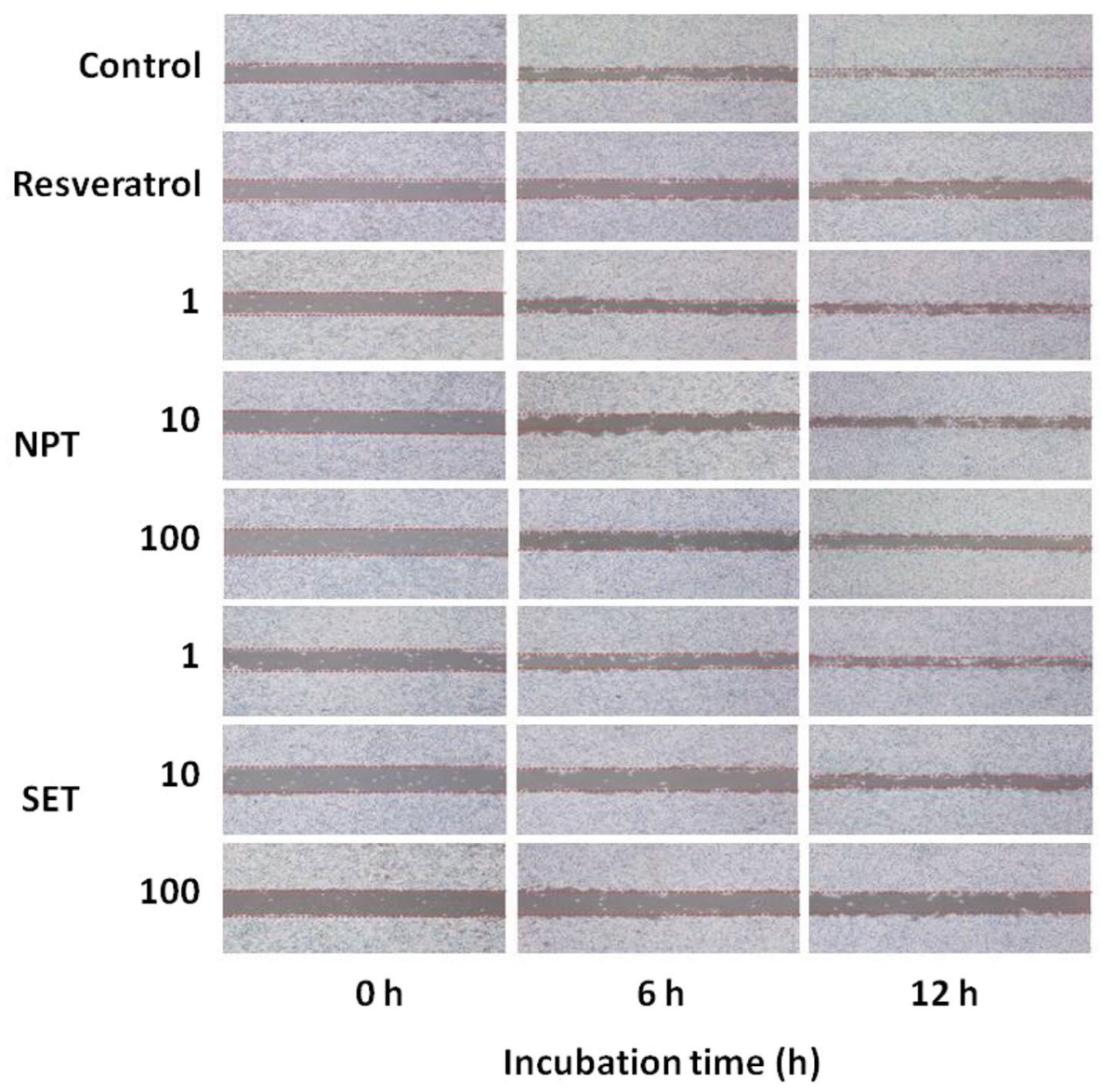

References research using human prostate cell [41]. The cell migration on the slit of the confluent wells was photographed after 0 , 6, and $12 \mathrm{~h}$ in each condition. As shown in Figs. 2(B) and 3 , there was a significant dose-dependent inhibitory effect on cell migration. The SET showed high inhibitory effects similar to the positive control $(10 \mu \mathrm{g} / \mathrm{mL}$, resveratrol). It was also reported that G. lucidum extracts suppress the growth of cancer cells [42, 43]; moreover, their biological activity and solubility were enhanced through sulfation [41]. In conclusion, the SET-processed G. lucidum extract showed the increase in the $\beta$-glucan extraction yield with the enhanced anti-metastatic effect on B16F10 cells. Therefore, it is suggested that SET process could be an effective way to develop the functional food from $G$. lucidum with anticancer activity.

Acknowledgments This work was supported by the Korea Institute of Planning and Evaluation for Technology in Food, Agriculture, Forestry (IPET) through the High Value-added Food Technology Development Program, funded by the Ministry of Agriculture, Food and Rural Affairs (MAFRA) (314070-3), the Government of the Republic of Korea.
1. Choi SJ, Lee YS, Kim JK, Kim JK, Lim SS (2010) Physiological activities of extract from edible mushrooms. J Korean Soc Food Sci Nutr 39:1087-1096

2. Chihara G, Hamuro J, Maeda YY, Arai Y, Fukuoka F (1970) Fractionation and purification of the polysaccharides with marked antitumor activity, especially Lentinan, from Lentinus edodes (Berk.) Sing, (an Edible Mushroom)1. Cancer Res 30:2776-2781

3. Bae WC, Kim YS, Lee JW (2005) Bioactive substances from Ganoderma lucidum. Korean J Microbiol Biotechnol 33:75-83

4. Yang Q, Wang S, Xie Y, Sun J, Wang J (2010) HPLC analysis of Ganoderma lucidum polysaccharides and its effect on antioxidant enzymes activity and Bax, Bcl-2 expression. Int J Biol Macromol 46:167-172

5. Zhong W, Liu N, Xie Y, Zhao Y, Song X, Zhong W (2013) Antioxidant and anti-aging activities of mycelial polysaccharides from Lepista sordida. Int J Biol Macromol 60:355-359

6. Pang X, Chen Z, Gao X, Liu W, Slavin M, Yao W, Yu LL (2007) Potential of a novel polysaccharide preparation (GLPP) from Anhui-grown Ganoderma lucidum in tumor treatment and immunostimulation. J Food Sci 72:S435-S442

7. Xu Z, Chen X, Zhong Z, Chen L, Wang Y (2011) Ganoderma lucidum polysaccharides: immunomodulation and potential antitumor activities. Am J Chin Med 39:15-27

8. Zhu XL, Chen AF, Lin ZB (2007) Ganoderma lucidum polysaccharides enhance the function of immunological effector cells in immunosuppressed mice. J Ethnopharmacol 111:219-226 
9. Xiao C, Wu QP, Cai W, Tan JB, Yang XB, Zhang JM (2012) Hypoglycemic effects of Ganoderma lucidum polysaccharides in type 2 diabetic mice. Arch Pharm Res 35:1793-1801

10. Zhu K, Nie S, Li C, Lin S, Xing M, Li W, Gong D, Xie M (2013) A newly identified polysaccharide from Ganoderma atrum attenuates hyperglycemia and hyperlipidemia. Int J Biol Macromol 57:142-150

11. Cho JH, Lee JY, Lee MJ, Oh HN, Kang DH, Jhune CS (2013) Comparative analysis of useful $\beta$-glucan and polyphenol in the fruiting bodies of Ganoderma spp. J Mushroom 11:164-170

12. Kohguchi M, Kunikata T, Watanabe H, Kudo N, Shibuya T, Ishihara T, Iwaki K, Ikeda M, Fukuda S, Kurimoto M (2004) Immuno-potentiating effects of the antler-shaped fruiting body of Ganoderma lucidum (Rokkaku-Reishi). Biosci Biotechnol Biochem 68:881-887

13. Park YJ, Nam JY, Yoon DE, Kwon OC, Kim HI, Yoo YB, Kong WS, Lee CS (2013) Comparison of anti-inflammatory, antioxidant and anti-allergic effects of Ganoderma species mycelial extracts. J Mushroom 11:111-115

14. Du B, Bian Z, Xu B (2014) Skin health promotion effects of natural beta-glucan derived from cereals and microorganisms: a review. Phytother Res 28:159-166

15. Zhu F, Du B, Bian Z, Xu B (2015) Beta-glucans from edible and medicinal mushrooms: characteristics, physicochemical and biological activities. J Food Compos Anal 41:165-173

16. Zhang M, Cui SW, Cheung PCK, Wang Q (2007) Antitumor polysaccharides from mushrooms: a review on their isolation process, structural characteristics and antitumor activity. Trends Food Sci Technol 18:4-19

17. Noh JE, Yoon SR, Lim AK, Kim HJ, Huh D, Kim DI (2012) A study on the yield of functional components of citrus peel extracts using optimized hot water extraction and enzymatic hydrolysis. Korean J Food Cook Sci 28:51-55

18. Lee SH, Jang GY, Kim KJ, Lee MJ, Kim TJ, Lee J, Jeong HS (2012) Effect of temperature, solvent concentration, and $\mathrm{pH}$ on the $\beta$-glucan extraction. Korean J Food Nutr 25:871-877

19. Benito-Román Ó, Alonso E, Cocero MJ, Goto M (2016) $\beta$-Glucan recovery from Ganoderma lucidum by means of pressurized hot water and supercritical $\mathrm{CO}_{2}$. Food Bioprod Process 98:21-28

20. Gil-Ramírez A, Clavijo C, Palanisamy M, Ruiz-Rodríguez A, Navarro-Rubio M, Marin FR, Reglero G, Soler-Rivas C (2013) Screening of edible mushrooms and extraction by pressurized water (PWE) of 3-hydroxy-3-methyl-glutaryl CoA reductase inhibitors. J Funct Foods 5:244-250

21. Smiderle FR, Morales D, Gil-Ramírez A, de Jesus LI, GilbertLópez B, Iacomini M, Soler-Rivas C (2017) Evaluation of microwave-assisted and pressurized liquid extractions to obtain $\beta$-d-glucans from mushrooms. Carbohydr Polym 156:165-174

22. Benito-Román Ó, Alvarez VH, Alonso E, Cocero MJ, Saldaña MDA (2015) Pressurized aqueous ethanol extraction of $\beta$-glucans and phenolic compounds from waxy barley. Food Res Int 75:252-259

23. Zheng HZ, Hwang IW, Chung SK (2009) Enhancing polyphenol extraction from unripe apples by carbohydrate-hydrolyzing enzymes. J Zhejiang Univ Sci B 10:912-919

24. Box GEP, Draper NR (1987) Empirical model-building and response surfaces. Wiley, New York

25. Lee HJ, Jung SK, Do JR, Kim HK (2015) Optimization of extraction conditions of sarcodon aspratus by response surface methodology. J Korean Soc Food Sci Nutr 44:464-469

26. Motilva MJ, Serra A, Borrás X, Romero MP, Domínguez A, Labrador A, Peiró L (2014) Adaptation of the standard enzymatic protocol (Megazyme method) to microplaque format for $\beta$ $(1,3)(1,4)$-d-glucan determination in cereal based samples with a wide range of $\beta$-glucan content. J Cereal Sci 59:224-227
27. Smith PK, Krohn RI, Hermanson GT, Mallia AK, Gartner FH, Provenzano MD, Fujimoto EK, Goeke NM, Olson DC, Klenk DC (1985) Measurement of protein using bicinchoninic acid. Anal Biochem 150:76-85

28. Dubois M, Gilles KA, Hamilton JK, Rebers PA, Smith F (1956) Colorimetric method for determination of sugars and related substances. Anal Biochem 28:350-356

29. Lee OH, Lee HB, Lee J, Son JY, Rhee SK, Kim HD, Kim YC, Lee BY (2005) Chemical properties of olive and bay leaves. J Korean Soc Food Sci Nutr 34:503-508

30. Mosmann T (1983) Rapid colorimetric assay for cellular growth and survival: application to proliferation and cytotoxicity assays. J Immunol Methods 65:55-63

31. Heo JC, Park JY, Lee JM, Kwon TK, Kim SU, Chung SK, Lee SH (2005) Wisteria floribunda gall extract inhibits cell migration in mouse $\mathrm{B} 16 \mathrm{~F} 1$ melanoma cells by regulating $\mathrm{CD} 44$ expression and GTP-RhoA activity. J Ethnopharmacol 102:10-14

32. Xu Y, Cai F, Yu Z, Zhang L, Li X, Yang Y, Liu G (2016) Optimisation of pressurised water extraction of polysaccharides from blackcurrant and its antioxidant activity. Food Chem 194:650-658

33. Ma C, Feng M, Zhai X, Hu M, You L, Luo W, Zhao M (2013) Optimization for the extraction of polysaccharides from Ganoderma lucidum and their antioxidant and antiproliferative activities. J Taiwan Inst Chem Eng 44:886-894

34. Mendes LC, de Menezes HC, Aparecida M, da Silva A (2001) Optimization of the roasting of robusta coffee $(C$. canephora conillon) using acceptability tests and RSM. Food Qual Prefer 12:153-162

35. Zheng HZ, Hwang IW, Kim SK, Lee SH, Chung SK (2010) Optimization of carbohydrate-hydrolyzing enzyme aided polyphenol extraction from unripe apples. J Korean Soc Appl Biol Chem 53:342-350

36. Guan X, Yao HY (2008) Optimization of Viscozyme L assisted extraction of oat bran protein using response surface methodology. Food Chem 106:345-351

37. Hwang IW, Chung SK, Jeong MC, Chung HS, Zheng HZ (2013) Optimization of enzymatic hydrolysis of persimmon peels for vinegar fermentation. J Korean Soc Appl Biol Chem 56:435-440

38. Matsunaga Y, Wahyudiono S, Machmudah S, Sasaki M, Goto M (2014) Hot compressed water extraction of polysaccharides from Ganoderma lucidum using a semibatch reactor. Asia Pac J Chem Eng 9:125-133

39. Chung H, Youn K (2005) Comparison of pretreatment methods for extraction of selected components from Ganoderma lucidum. Korean J Food Preserv 12:130-134

40. Lai L, Yang D (2007) Rheological properties of the hot-water extracted polysaccharides in Ling-Zhi (Ganoderma lucidum). Food Hydrocoll 21:739-746

41. Wan-Mohtar WAAQ, Young L, Abbott GM, Clements C, Harvey LM, McNeil B (2016) Antimicrobial properties and cytotoxicity of sulfated $(1,3)-\beta$-D-glucan from the mycelium of the mushroom Ganoderma lucidum. J Microbiol Biotechnol 26:999-1010

42. Barbieri A, Quagliariello V, Del Vecchio V, Falco M, Luciano A, Amruthraj NJ, Nasti G, Ottaiano A, Berretta M, Iaffaioli RV, Arra C (2017) Anticancer and anti-inflammatory properties of Ganoderma lucidum extract effects on melanoma and triplenegative breast cancer treatment. Nutrients 9:210

43. Loganathan J, Jiang J, Smith A, Jedinak A, Thyagarajan-Sahu A, Sandusky GE, Nakshatri H, Sliva D (2014) The mushroom Ganoderma lucidum suppresses breast-to-lung cancer metastasis through the inhibition of pro-invasive genes. Int $\mathrm{J}$ Oncol 44:2009-2015 